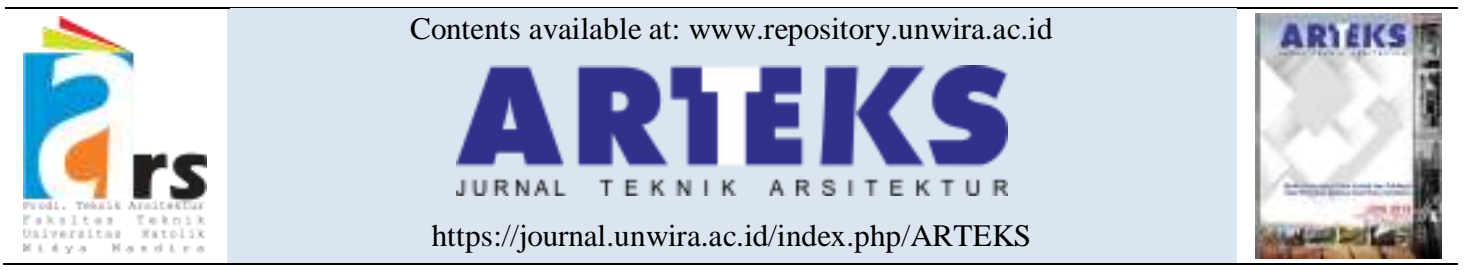

Research paper

doi: 10.30822/arteks.v6i2.715

\title{
The green-based school and the creation of student's environmental attitude and behavior
}

\author{
Restika R. Efiariza, Ova Candra Dewi* ${ }^{*}$, Toga H. Panjaitan, Rizka Felly
}

Department of Architecture, Faculty of Engineering, Universitas Indonesia

Kampus UI Depok, Jawa Barat, Indonesia

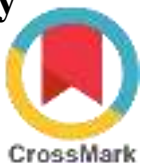

\begin{tabular}{|c|c|}
\hline ARTICLE INFO & ABSTRACT \\
\hline $\begin{array}{l}\text { Article history: } \\
\text { Received October } 24,2020 \\
\text { Received in revised form Nov. 01, } 2020 \\
\text { Accepted Dec. } 11,2020 \\
\text { Available online August } 01,2021\end{array}$ & $\begin{array}{l}\text { This study examines the relationship between the green-based } \\
\text { school with students' environmental attitudes and behavior. } \\
\text { Sustainable development has become the solution and commitment } \\
\text { to save the earth from destruction due to human behavior. } \\
\text { Environmental education plays an important role in creating an }\end{array}$ \\
\hline $\begin{array}{l}\text { *Corresponding author: Ova Candra Dewi } \\
\text { Department of Architecture, Faculty of } \\
\text { Engineering, Universitas Indonesia } \\
\text { Email: ova.candewi@ui.ac.id } \\
\text { ORCID: https://orcid.org/0000-0001-5418- } \\
\text { 3146 }\end{array}$ & $\begin{array}{l}\text { environmentally literate society. Adiwiyata School, an official form } \\
\text { of environmental education, is one of the efforts to increase } \\
\text { sustainable development through education as a way to improve } \\
\text { student's environmental attitude and behavior. The research design } \\
\text { used multiple case studies utilizing the observation method and } \\
\text { questionnaire distribution to Adiwiyata and non-Adiwiyata schools. } \\
\text { A New Ecological Paradigm (NEP) scale and a General Ecological } \\
\text { Behavior (GEB) scale are used to measure student's environmental } \\
\text { attitudes and behavior change. As a result, the green-based school } \\
\text { creates influences in student's environmental attitudes (9.3\%) and } \\
\text { environmental behavior (12.3\%). }\end{array}$ \\
\hline
\end{tabular}

\section{Introduction}

Environmental problems occur due to a lack of human interaction, awareness, and understanding of the environment (BowoSantoso 2015; Meiboudi et al. 2018; Subroto 2019; Widodo 2019). Sustainable development has become a commitment and responsibility to save the earth (Pradono 2019). Organizations and governments create great efforts in several countries (Zhao, He, and Meng 2015), such as enacting agreements, laws, standards, and regulations to encourage people to accelerate the transition to sustainable development (Almeida et al. 2015). The Indonesian government and the international community have agreed on the importance of protecting the earth from pollution and damage. One of the government's commitments is to conduct this through the implementation of education, which is the key to preparing humans with knowledge, understanding, expertise, values, and attitudes (Ministry of Environment 2012). Schools are the most effective media in disseminating environmental education and dealing with environmental problems at an early stage (Razak, Iksan, and Zakaria 2017). As a unique community, school is not only aimed at fulfilling cognitive needs but also providing education about the environment, skills, responsible behavior, and spreading the concept of environmental awareness to its students (Zhao, He, and Meng 2015). It is one of the best ways to shape environmental behavior by developing facilities that reduce the burden on the environment. Human efforts and behavior are very important to solve environmental problems (Kurisu 2015). Adiwiyata school is one of the public schools that implements an environmental education (EE) system in Indonesia. Adiwiyata school is a school that has received the Adiwiyata 
award as a reward for its participation in an environmental conservation program and implementation of EE in schools (Ministry of Environment 2012). Children who grow up in the EE system will lead what they learn at their homes and surroundings, so they will contribute to a green environment later (Meiboudi et al. 2018). A person's behavior patterns change when they learn from their environment (Cummings 2012).

Green open spaces initiate awareness on human health (Dewi et al. 2018). It is important to find out architectural factors from green-based schools to comprehend environmental attitudes and behavior. School design plays an important role in inhibiting, encouraging, and facilitating behavior in school. Moreover, schools should be able to create green architectural designs since architecture is a pedagogical tool for environmental education. The physical elements in the school environment can provide cues to learn (Tucker and Izadpanahi 2017). A study on the relationship between school design and student achievement has been widely studied. Meanwhile, a study on the relationship between green school designs and students' environmental attitudes and behaviors is only slightly brought up. Therefore, a deeper understanding of the relationship between the built environment and environmental attitudes and behavior in students is required.

This study examines the relationship between the green-based school with a student's environmental attitudes and behavior. Additionally, it examines whether the greener features applied in the school have a greater impact on supporting the development of student's environmental attitudes and behavior. This study is expected to bring a revolution in school design and construction, especially in the school's-built environment based.

\section{Method}

According to (Izadpanahi 2015), environmental education aims to create individuals who behave environmentally friendly or to change individual behavior into positive behavior towards the environment. In achieving its goal there are three different approaches in environmental education: (1) through the school curriculum, (2) through the environmental initiatives, which focus on programs such as field trips or other outdoor activities, (3) through the built environment. This approach uses architecture as a mediation to communicate environmental concepts to the school community in indoor and outdoor areas (Izadpanahi 2015). Environmental education through the built environment or architectural side will be discussed in this study.

The built environment provides space in shaping behavior (Asyera 2019). The built environment is a physical environment or space around the individual, where behavior can be formed. The individual's behavior relates to the surroundings and how the individual responds to what they see, touches, hears and smells (Griskevicius, Cantú, and van Vugt 2012). Green schools are built environments for school members that aim to instill environmental education and promote initiatives towards sustainable development. The criteria for green school based on environmental design include location, position and condition of the building, indoor air criterion, green space, material, water conservation, energy conservation, waste management, safety, security and health, ecomanagement, green education, transportation, and participation. These criteriums will be developed by authors and used as parameters of the greenbased school assessment in this study as contained in table two.

This study used multiple case studies because based on theory, to explain an issue by presenting more pieces of evidence and facts can improve the understanding of the issue or a theory (Stake 2005; Creswell 2012). This study compares Adiwiyata schools of different rankings (city, province, national, and independent level), and also the non-Adiwiyata public schools as a comparison. A quantitative approach is used. The purpose, samples, research questions, and the entire study process are predetermined. The designs and green features applied in schools, as well as student's environmental attitudes and behaviors are all reviewed in this study. The research variables are quantified to produce data in the form of numbers used for analysis. The data is collected qualitatively through the observation method and questionnaires distribution to Adiwiyata and non-Adiwiyata schools.

\section{Location and respondent}

As in table 1, this study is conducted at five schools in Padang city with the following school criteria: (1) must be a public school in Padang city and registered as an educational institution 
recognized by the Ministry of Education and Culture. Public schools are chosen as they have roughly the same design, so they can be compared, (2) Four selected public junior high schools, all of which bearing Adiwiyata of different ranks (city, province, national, and independent) at least in the last of approximately one year, (3) One public junior high school that is not registered as an Adiwiyata school. Every school is given the initials A, B, C, D, and E to safeguard the data privacy of the study object.

The respondents are male and female students of grades 8 and 9, aged 13-15 years, and registered as the school's student for at least one year. The process of behavior forming takes about 1-5 years (Prochaska and Velicer 1997). Total respondents are 240 students according to the calculation result using the G-Power software. Every school consists of 48 respondents with the same amount of gender and grades. This is based on the study that will calculate the significant value and average value of the measuring instrument used.

Table 1. Location and respondent of the study

\begin{tabular}{llcc}
\hline $\begin{array}{l}\text { School } \\
\text { name }\end{array}$ & $\begin{array}{l}\text { Predicate/ } \\
\text { level }\end{array}$ & $\begin{array}{l}\text { Predicate } \\
\text { year }\end{array}$ & Respondent \\
\hline $\begin{array}{l}\text { School } \\
\text { A }\end{array}$ & $\begin{array}{l}\text { Non- } \\
\text { Adiwiyata }\end{array}$ & - & 48 \\
\hline School B & $\begin{array}{l}\text { Adiwiyata } \\
\text { city }\end{array}$ & 2017 & 48 \\
\hline School C & $\begin{array}{l}\text { Adiwiyata } \\
\text { province }\end{array}$ & 2018 & 48 \\
\hline $\begin{array}{l}\text { School } \\
\text { D }\end{array}$ & $\begin{array}{l}\text { Adiwiyata } \\
\text { national }\end{array}$ & 2018 & 48 \\
\hline School E & $\begin{array}{l}\text { Adiwiyata } \\
\text { independent }\end{array}$ & 2010 & 48 \\
\hline
\end{tabular}

Green-based school assessment tools

Table 2 shows one of the parameters in this study. These parameters are the result of several literature studies on sustainable school-built environments or the so-called green-based school in this study. Used as an assessment tool for the green-based school, A, B, C, D, and E related to the physical design and school facilities. There were 6 categories with 29 sub-categories to be assessed. The maximum and minimum points are 80 points and the 29 points respectively.

Table 2. Parameters of green- based school assessment

\begin{tabular}{llc}
\hline Parameters & Sub-parameters & Source \\
\hline Outdoor & & \\
\hline Open space & $\begin{array}{l}\text { Minimum } \geq 30 \% \text { of the } \\
\text { total site area } \\
\text { (including buildings) }\end{array}$ & {$[1][2][3]$} \\
Grass & $\begin{array}{l}\text { Minimum } \geq 25 \% \text { of the } \\
\text { outdoor grass-planted }\end{array}$ & {$[4]$} \\
\hline
\end{tabular}

\begin{tabular}{|c|c|c|}
\hline Parameters & Sub-parameters & Source \\
\hline & $\begin{array}{l}\text { area (excluding } \\
\text { vegetation) }\end{array}$ & \\
\hline Pedestrian & $\begin{array}{l}\text { Easily accessible and } \\
\text { using paving blocks }\end{array}$ & {$[3][4]$} \\
\hline Vegetation & $\begin{array}{l}\text { Many native flowers, } \\
\text { plants, and trees }\end{array}$ & [1] [3] [4] \\
\hline Materials & $\begin{array}{l}\text { Use eco-friendly and } \\
\text { recycling materials }\end{array}$ & $\begin{array}{c}\text { [1] [3] [4] } \\
{[5]}\end{array}$ \\
\hline $\begin{array}{l}\text { Biomorphic } \\
\text { patterns }\end{array}$ & $\begin{array}{l}\text { Lots of natural patterns } \\
\text { and shapes }\end{array}$ & [6] \\
\hline \multicolumn{3}{|c|}{ Indoor (classroom) } \\
\hline Vegetation & $\begin{array}{l}\text { Many native flower } \\
\text { and plants }\end{array}$ & [1] [3] \\
\hline Furniture & $\begin{array}{l}\text { Use eco-friendly and } \\
\text { recycling furniture }\end{array}$ & \multirow[b]{2}{*}{$\begin{array}{c}{[1][3][4]} \\
{[5]}\end{array}$} \\
\hline Materials & $\begin{array}{l}\text { Use local, recycled, } \\
\text { and environmentally } \\
\text { friendly materials. }\end{array}$ & \\
\hline $\begin{array}{l}\text { Biomorphic } \\
\text { patterns }\end{array}$ & $\begin{array}{l}\text { Lots of materials and } \\
\text { furniture with } \\
\text { biomorphic patterns } \\
\text { and shapes }\end{array}$ & {$[6]$} \\
\hline Ventilation & $\begin{array}{l}\text { Many windows and } \\
\text { well-functioning. }\end{array}$ & {$[3][5]$} \\
\hline $\begin{array}{l}\text { Green space } \\
\text { access }\end{array}$ & $\begin{array}{l}\text { Have direct access to } \\
\text { the green space }\end{array}$ & {$[3][4]$} \\
\hline Electrical & $\begin{array}{l}\text { Energy-efficient } \\
\text { artificial light }\end{array}$ & \multirow{2}{*}{$\begin{array}{c}{[1][3][4]} \\
{[5][7]}\end{array}$} \\
\hline $\begin{array}{l}\text { Air } \\
\text { conditioning }\end{array}$ & $\begin{array}{l}\text { Not using AC (air } \\
\text { conditioning) or fan }\end{array}$ & \\
\hline $\begin{array}{l}\text { Campaign } \\
\text { posters }\end{array}$ & $\begin{array}{l}\text { Have three categories } \\
\text { of campaign posters } \\
\text { (water/waste/energy) }\end{array}$ & \multirow[b]{2}{*}[3]{$[5][7]$} \\
\hline $\begin{array}{l}\text { Campaign } \\
\text { poster shape } \\
\text { and position }\end{array}$ & $\begin{array}{l}\text { Each poster lies in its } \\
\text { respective place, with a } \\
\text { striking shape and } \\
\text { color. }\end{array}$ & \\
\hline $\begin{array}{l}\text { Classroom } \\
\text { orientation }\end{array}$ & $\begin{array}{l}\text { Classroom openings } \\
\text { lead to north or south } \\
\text { and have trees to filter } \\
\text { the wind and sunlight. }\end{array}$ & \multirow[t]{2}{*}{$\begin{array}{c}{[1][2][3]} \\
{[5]}\end{array}$} \\
\hline $\begin{array}{l}\text { Classroom } \\
\text { position }\end{array}$ & $\begin{array}{l}\text { Away from highways } \\
\text { and parking lots }\end{array}$ & \\
\hline \multicolumn{3}{|c|}{ Facilities of Green Education } \\
\hline \multicolumn{2}{|c|}{$\begin{array}{l}\text { Have green education facilities in school } \\
\text { (greenhouse, garden, fish pond, bio pore, } \\
\text { hydroponics, etc.) }\end{array}$} & {$[8]$} \\
\hline \multicolumn{3}{|c|}{ Waste management } \\
\hline Bins & $\begin{array}{l}\text { Have sorted bins in } \\
\text { most classes with easy } \\
\text { access. }\end{array}$ & \multirow{2}{*}{$\begin{array}{c}{[1][2][4]} \\
{[5][7]}\end{array}$} \\
\hline $\begin{array}{l}\text { Garbage } \\
\text { dump }\end{array}$ & $\begin{array}{l}\text { Have sorted garbage } \\
\text { dump with easy access }\end{array}$ & \\
\hline Poster/Sign & $\begin{array}{l}\text { Have a sign in the bins } \\
\text { and garbage dump }\end{array}$ & [3] [5] [7] \\
\hline Composter & Have composter area & [5] [7] \\
\hline \multicolumn{3}{|c|}{ Water management } \\
\hline $\begin{array}{l}\text { Water } \\
\text { features }\end{array}$ & $\begin{array}{l}\text { Use water-efficient } \\
\text { toilets and faucet }\end{array}$ & \multirow{2}{*}{$\begin{array}{c}{[2][3][4]} \\
{[5][7]}\end{array}$} \\
\hline Irrigation & $\begin{array}{l}\text { Have a rainwater } \\
\text { collection system that } \\
\text { is easily accessible. }\end{array}$ & \\
\hline
\end{tabular}




\begin{tabular}{|c|c|c|}
\hline Parameters & Sub-parameters & Source \\
\hline Poster/Sign & $\begin{array}{l}\text { Have a sign in the } \\
\text { toilets \& sink that is } \\
\text { easily visible. }\end{array}$ & [3] [5] [7] \\
\hline Plants & $\begin{array}{l}\text { Have water } \\
\text { conservation plants }\end{array}$ & [3] [4] [7] \\
\hline \multicolumn{3}{|c|}{ Energy management } \\
\hline $\begin{array}{l}\text { Monitoring } \\
\text { screen }\end{array}$ & $\begin{array}{l}\text { Use energy monitoring } \\
\text { screen that is easily } \\
\text { accessible for the } \\
\text { students }\end{array}$ & [3] [6] [9] \\
\hline Poster/Sign & Have a sign-in electric & [3] [5] [7] \\
\hline \multicolumn{3}{|c|}{$\begin{array}{l}\text { Notes: } \\
\text { [1]: (Meiboudi et al. 2018); [2]: (Filippi and Sirombo } \\
\text { 2015); [3]: (Krysiak, Young, and Fearns 2018); [4]: } \\
\text { (NYC School Construction Authority \& NYC } \\
\text { Department of Education 2019); [5]: (Ramli et al. 2012); } \\
\text { [6]: (Cummings 2012); [7]: (Goldman et al. 2018); [8]: } \\
\text { (Ministry of Environment 2012); [9]: (Lockton, } \\
\text { Harrison, and Stanton 2008). }\end{array}$} \\
\hline
\end{tabular}

Environmental attitude and behavior assessment tools

New Ecological Paradigm scale and General Ecological Behavior scale adapted from the study (Tucker and Izadpanahi 2017; Yusup and Munandar 2015) were used in this study. The use of these two measuring instruments was motivated because this study examines schools, which is expected to affect the cognitive and behavior of students. The adaptation of these measuring instruments was carried out with experts. The reliability statistics of the NEP and GEB scale have met the standard (>0.05), with the Alpha Cronbach coefficient of 0.799 for NEP and 0.659 for GEB. Thus, each item in both measuring instruments is reliable in this study.

On this scale, the Author adds an image to each item to make it easier for students to understand the meaning of the question and to increase student attractiveness. A Likert scale that was reduced to a 4-point scale by removing neutral options is used to avoid centration (Djuwita and Benyamin 2019).

New Ecological Paradigm (NEP) scale

NEP scale is an assessment instrument to measure student's attitudes and views of the environment (Tucker and Izadpanahi 2017). It consists of 15 items and 3 dimensions, namely human intervention, Education for Sustainable Development (ESD) at school, and eco-rights as in table 3.
Table 3. NEP scale

\begin{tabular}{|c|c|}
\hline Items & Dimensions \\
\hline $\begin{array}{l}\text { If humans continue to destroy nature, } \\
\text { then we will shortly face a major } \\
\text { environmental disaster. }\end{array}$ & \multirow{5}{*}{$\begin{array}{l}\text { Human } \\
\text { intervention }\end{array}$} \\
\hline $\begin{array}{l}\text { One day humans will understand how } \\
\text { nature works so they can control it. }\end{array}$ & \\
\hline $\begin{array}{l}\text { When humans destroy nature, there will } \\
\text { be a bad impact. }\end{array}$ & \\
\hline $\begin{array}{l}\text { Humans are smart enough to not destroy } \\
\text { the earth. }\end{array}$ & \\
\hline Humans treat nature badly. & \\
\hline $\begin{array}{l}\text { I want to go to a school that cares about } \\
\text { nature. }\end{array}$ & \multirow{5}{*}{$\begin{array}{l}\text { ESD at } \\
\text { school }\end{array}$} \\
\hline $\begin{array}{l}\text { I believe that the light in the classroom } \\
\text { should be produced by solar panels. }\end{array}$ & \\
\hline $\begin{array}{l}\text { I am willing to grow vegetables in the } \\
\text { school garden. }\end{array}$ & \\
\hline $\begin{array}{l}\text { I feel closer to nature when classes are } \\
\text { held in the outdoors. }\end{array}$ & \\
\hline $\begin{array}{l}\text { I feel better when I get natural light than } \\
\text { artificial light while in the classroom. }\end{array}$ & \\
\hline $\begin{array}{l}\text { Humans must still obey the laws of } \\
\text { nature. }\end{array}$ & \multirow{5}{*}{ Eco-rights } \\
\hline $\begin{array}{l}\text { Nature will survive even with the bad } \\
\text { habits of humans on earth. * }\end{array}$ & \\
\hline $\begin{array}{l}\text { Humans should rule all the whole nature } \\
\text { well. }\end{array}$ & \\
\hline $\begin{array}{l}\text { Plants and animals have the same right } \\
\text { to live as humans. }\end{array}$ & \\
\hline Humans may destroy nature. $*$ & \\
\hline
\end{tabular}

General Ecological Behavior (GEB) scale

GEB scale is an assessment instrument to measure students's environmental behavior from simple things to behavior that requires great commitment and sacrifice (Tucker and Izadpanahi 2017). It consists of 11 items and 2 dimensions, namely pro-active eco-behaviors and resource and energy conservation as in table 4 .

Table 4. GEB scale

\begin{tabular}{|c|c|}
\hline Items & Dimensions \\
\hline $\begin{array}{l}\text { I participated in recycling activities at } \\
\text { school. }\end{array}$ & \multirow{6}{*}{$\begin{array}{l}\text { Pro-active } \\
\text { Eco-behaviors } \\
\text { Resource }\end{array}$} \\
\hline $\begin{array}{l}\text { I help the teacher to take care of and } \\
\text { clean the school garden. }\end{array}$ & \\
\hline $\begin{array}{l}\text { I read books about the environment } \\
\text { (nature, trees, and animals). }\end{array}$ & \\
\hline $\begin{array}{l}\text { I pick up the trash left by my friends } \\
\text { during recess and lunch. }\end{array}$ & \\
\hline $\begin{array}{l}\text { I use scrap paper with the back blank } \\
\text { as scribbles for my math calculations. }\end{array}$ & \\
\hline $\begin{array}{l}\text { I separate organic and inorganic waste } \\
\text { before disposal. }\end{array}$ & \\
\hline $\begin{array}{l}\text { I didn't turn on the class lights because } \\
\text { the light in my class was already } \\
\text { bright. }\end{array}$ & \multirow{2}{*}{$\begin{array}{l}\text { Resource and } \\
\text { Energy } \\
\text { Conservation }\end{array}$} \\
\hline $\begin{array}{l}\text { I forget to turn off the water after } \\
\text { washing my hands in the school toilet. } \\
*\end{array}$ & \\
\hline
\end{tabular}




\begin{tabular}{l}
\hline Items \\
\hline I bring too many supplies to school, so \\
it should be thrown away. * \\
\hline I prefer to turn on the fan/air \\
conditioning than opening a window \\
when the room feels hot. * \\
\hline I forgot to turn off the light when I left \\
the classroom. * \\
Source: adaptation of (Tucker and Izadpanahi 2017; \\
Yusup and Munandar 2015)
\end{tabular}

\section{Result and discussion}

Due to the Covid-19 pandemic, the green-based school assessment process was switched by taking image data by other parties who have expertise in the field of architecture according to predetermined parameters. Furthermore, measuring students' environmental attitudes and behavior with NEP and GEB scale is performed online through the google forms application.

\section{School built environment analysis}

Table 5. School built environment A, B, C, D, and Eassessment

\begin{tabular}{l} 
Pchool \\
\hline School A - non Adiwiyata
\end{tabular}

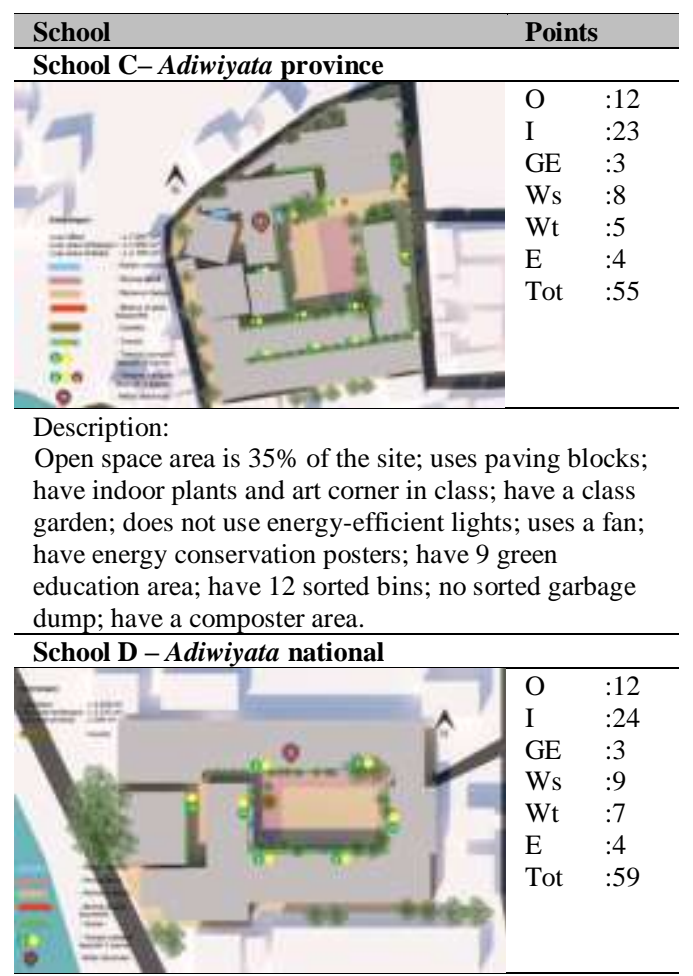

Description:

Open space area is $23 \%$ of the site; uses paving blocks; have indoor plants and art corner in class; have a class garden; does not use energy-efficient lights; uses a fan; have energy and water conservation posters; have 10 green education areas; have 7 sorted bins with stickers; have a garbage bank; have a composter area

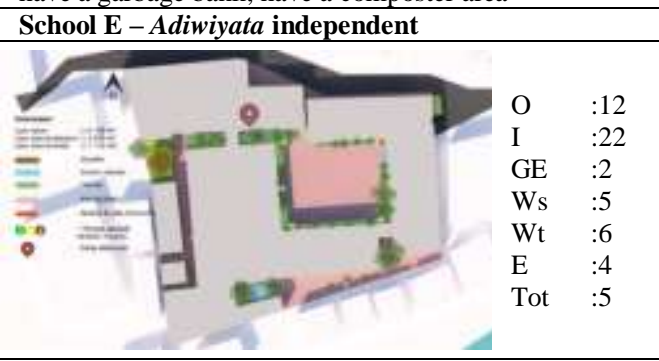

\section{Description:}

Open space area is $28 \%$ of the site; uses paving blocks; uses a lot of recycled furniture; have murals on school walls; have indoor plants and art corner in the class, have a class garden; many wider windows; does not use energy-efficient lights; uses a fan; have water conservation poster; have 10 green education area; have 7 sorted bins; have garbage bank; have composter area.

Table 5 shows, school A, B, C, D, and E get $46,51,55,59$, and 54 points respectively. School D was declared the best school in implementing green features in its environment, especially in waste management and water conservation. In general, Adiwiyata schools (schools B, C, D, E) implement better green features than non- 
Adiwiyata schools (school A), except for waste management actions.

Students' environmental attitude and behavior analysis

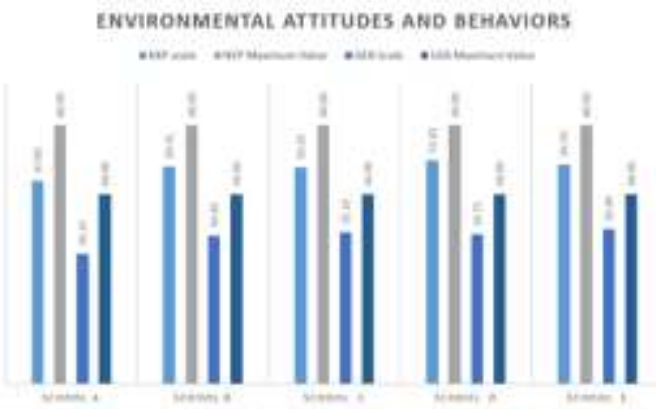

Figure 1. Student's environmental attitudes and behavior

The results of the NEP and GEB scale calculations in figure 1 found that student A obtained the lowest scores for environmental attitudes and behaviors among the other four schools, namely 47 points for the NEP scale and 30.19 points for the GEB scale. Student $\mathrm{D}$ had the highest environmental attitude points with a total of 51.81/60 points. Meanwhile, student $\mathrm{E}$ had the highest environmental behavior points with a total of 35.90/44 points. The highest average of environmental attitude and behavior achieved by student $E$ with a total of 86.69 points, followed by students D, C, B, and A.

Adiwiyata schools have higher environmental attitude and behavior points than non-Adiwiyata schools. However, among the Adiwiyata schools (B, C, D, and E), schools with higher built environmental points did not always have high environmental attitude and behavior points as well. For example, school E, which get third-place for in-built environmental points, yet the student $\mathrm{E}$ had the highest average points for environmental attitude and behavior. School D gets the highest built environmental points, yet student $\mathrm{D}$ had a point average in the second rank or lower than school E students. This is due to the influence of the year implementation and the acquisition of Adiwiyata awards. For example, schools D and $\mathrm{C}$ that have a higher built environment than school $\mathrm{E}$ because they get the national and province-level Adiwiyata awards in 2018. Meanwhile, school E gets the independent Adiwiyata award in 2010. Thus, the built environment of D and C was still well controlled.
Meanwhile school E, as a school that first implemented environmental-based education, was deemed to be better prepared and accustomed to developing environmental attitudes and behaviors for its students, even though its built environmental points are not better than D and C.

Table 6. The significance of NEP points comparison between schools A, B, C, D, and E

\begin{tabular}{|c|c|c|c|c|c|}
\hline NEP & A & B & C & D & $\mathbf{E}$ \\
\hline A & - & $\begin{array}{l}\text { Sig } \\
0.121 \\
\text { Not sig } \\
\text { R } 1.5 \%\end{array}$ & $\begin{array}{l}\text { Sig } \\
0.106 \\
\text { Not sig } \\
\text { R } 1.1 \%\end{array}$ & $\begin{array}{l}\text { Sig } \\
0.304 \\
\text { Sig. } \\
\text { R 9.2\% }\end{array}$ & $\begin{array}{l}\text { Sig } \\
0.046 \\
\text { Not sig } \\
\text { R } 0.2 \%\end{array}$ \\
\hline B & - & - & $\begin{array}{l}\text { Sig } \\
0.124 \\
\text { Not sig } \\
\text { R } 1.5 \% \\
\end{array}$ & $\begin{array}{l}\text { Sig } \\
0.097 \\
\text { Not sig } \\
\text { R 0.9\% } \\
\end{array}$ & $\begin{array}{l}\text { Sig } \\
0.065 \\
\text { Not sig } \\
\text { R } 0.4 \% \\
\end{array}$ \\
\hline $\mathrm{C}$ & - & - & - & $\begin{array}{l}\text { Sig } \\
0.106 \\
\text { Not sig } \\
\text { R } 1.1 \% \\
\end{array}$ & $\begin{array}{l}\text { Sig } \\
0.032 \\
\text { Not sig } \\
\text { R } 0.1 \%\end{array}$ \\
\hline D & - & - & - & - & $\begin{array}{l}\text { Sig } \\
0.160 \\
\text { Not sig } \\
\text { R } 1.7 \%\end{array}$ \\
\hline E & - & - & - & - & - \\
\hline
\end{tabular}

The test results of differences in significance value from IBM SPSS software in Table 6 showed that $90 \%$ of the NEP points among schools were not significant. Except for NEP points between school A and school D with a point difference of 4.81. A significant difference in environmental attitudes in this study occurred if it had a difference of points $\geqslant 4.81$. Students A, B, C, and $\mathrm{E}$ had the same level of environmental attitudes, while student $\mathrm{D}$ had a better environmental attitude than student A. The effect of the greenbased school on student's environmental attitudes in this study was only $9.2 \%$ at maximum. This was due to the shaping of student's environmental attitudes that are more influenced by teaching factors as environmental attitudes are related to students' views or beliefs about the environment that can be taught by teachers and students' families (Tucker and Izadpanahi 2017).

Table 7. The significance of GEB points comparison between schools A, B, C, D, and E

\begin{tabular}{llllll}
\hline GEB & A & B & C & D & E \\
\hline & & Sig & Sig & Sig & Sig \\
A & - & 0.260 & 0.226 & 0.261 & 0.276 \\
& & Sig. & Sig. & Sig. & Sig. \\
& R 6.7\% & R 5.1\% & R 6.7\% & R 7.6\% \\
\hline
\end{tabular}




\begin{tabular}{|c|c|c|c|c|c|}
\hline GEB & $\mathbf{A}$ & B & $\mathrm{C}$ & D & $\mathbf{E}$ \\
\hline B & - & - & $\begin{array}{l}\text { Sig } \\
0.306 \\
\text { Sig. } \\
\text { R } 9.4 \%\end{array}$ & $\begin{array}{l}\text { Sig } \\
0.047 \\
\text { Not sig } \\
\text { R } 0.2 \%\end{array}$ & $\begin{array}{l}\text { Sig } \\
0.388 \\
\text { Sig. } \\
\text { R } \\
15.1 \%\end{array}$ \\
\hline $\mathrm{C}$ & - & - & - & $\begin{array}{l}\text { Sig } \\
0.15 \\
\text { Not sig } \\
\text { R } 0 \% \\
\end{array}$ & $\begin{array}{l}\text { Sig } \\
0.230 \\
\text { Sig. } \\
\text { R 5.3\% }\end{array}$ \\
\hline D & - & - & - & - & $\begin{array}{l}\text { Sig } \\
0.117 \\
\text { Not sig } \\
\text { R } 1.4 \%\end{array}$ \\
\hline $\mathrm{E}$ & - & - & - & - & - \\
\hline
\end{tabular}

As in table $7,70 \%$ of GEB points among schools are significant. A significant difference in environmental behavior in this study occurred if it had a difference of $\geqslant 4.25$. This means that students $\mathrm{B}, \mathrm{C}, \mathrm{D}$, and $\mathrm{E}$ have better environmental behavior than student A. Adiwiyata's students (B, $\mathrm{C}, \mathrm{D}$, and E) have similar or insignificant environmental behaviors. The green-based school affects the student's environmental behavior by $5.1 \%-15.1 \%$. Green features in schools have an influence on students' behavior that can be seen from the green features applied to Adiwiyata schools (B, C, D, and E) more than school A. This was because sustainability practices can change the environmental behavior of the users (Cummings 2012).

Table 8. Correlation test result of green-based school with student's attitudes and environmental behaviors

\begin{tabular}{lll}
\hline & $\begin{array}{l}\text { NEP scale } \\
\text { significance value }\end{array}$ & $\begin{array}{l}\text { GEB scale } \\
\text { significance value }\end{array}$ \\
\hline $\begin{array}{l}\text { Green-based } \\
\text { school }\end{array}$ & Sig. 0.000 & Sig. 0.000 \\
\hline \multirow{2}{*}{$\begin{array}{l}\text { Degree of } \\
\text { correlation } \\
\text { level }\end{array}$} & $\begin{array}{l}\text { Pearson } \\
\text { correlation: } \\
0.305\end{array}$ & $\begin{array}{l}\text { Pearson } \\
\text { Correlation: } \\
0.350\end{array}$ \\
\cline { 2 - 3 } & R square 9.3\% & R square 12.3\% \\
\hline \multirow{2}{*}{ Relationship } & $\begin{array}{l}\text { Weak correlation, } \\
\text { positive } \\
\text { relationships }\end{array}$ & $\begin{array}{l}\text { Weak correlation, } \\
\text { positive } \\
\text { relationships }\end{array}$ \\
\hline
\end{tabular}

*Notes:

Sig: significant level $(<0.05)$;

Pearson correlation: the degree of relationship;

$\mathrm{R}$ Square: percentage relationship rate.

Correlation test results from IBM SPSS software in all schools in table 8 found that there was a correlation between the green-based school and students' environmental attitudes and behavior. Overall the formed correlation is a positive correlation, which means that the higher the green-based school, the higher the formed the attitudes and behavior of the students' environment. However, the degree of correlation formed was weak.

Analysis of student behavior in schools based on GEB scale results

The results of the GEB scale analysis related to the response of student behavior to the school space are shown in figure 2 till 4 . Three elements have the highest relationship with students' environmental behavior based on the recapitulation in 5 schools: garden, classroom ventilation, and recycling area.

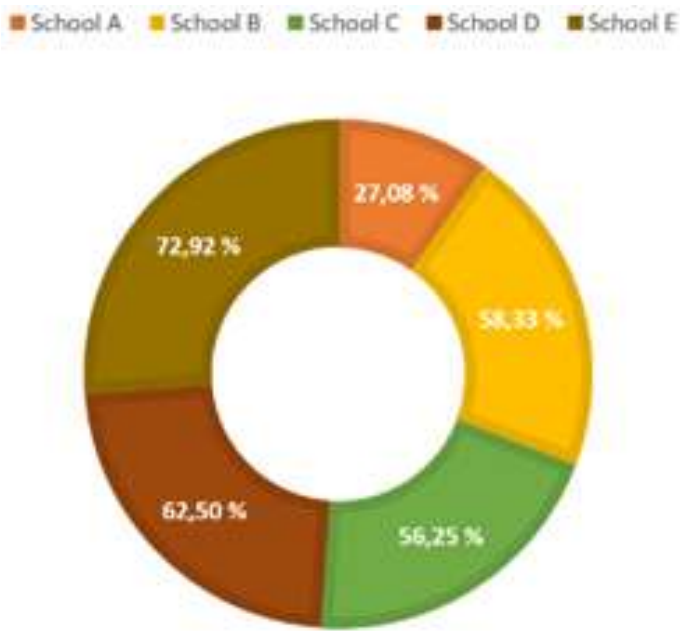

Figure 2. Percentage of student participation in recycling activities

Figure 2 shows that students B, C, D, and E (Adiwiyata school) did more recycling activities with a percentage of $58.33 \%, 56.25 \%, 62.50 \%$, and $72.92 \%$ respectively. Student A only gained a percentage of $27.08 \%$.

The availability of composter areas and art corners (recycled art space in class) at schools B, $\mathrm{C}, \mathrm{D}$, and $\mathrm{E}$ can encourage recycling activities in their schools. Additionally, the availability of waste banks at schools D and E increased student participation in recycling activities and also decreased the number of students who never participated in recycling activities.

From the results of the significance, the test showed that the recycling spaces affected student recycling behavior by $58.8 \%$. The more availability of recycling space the higher the 
recycling activity, and the more significant the recycling behavior is formed. Thus, to improve student recycling behavior, schools should provide lots of recycling space.

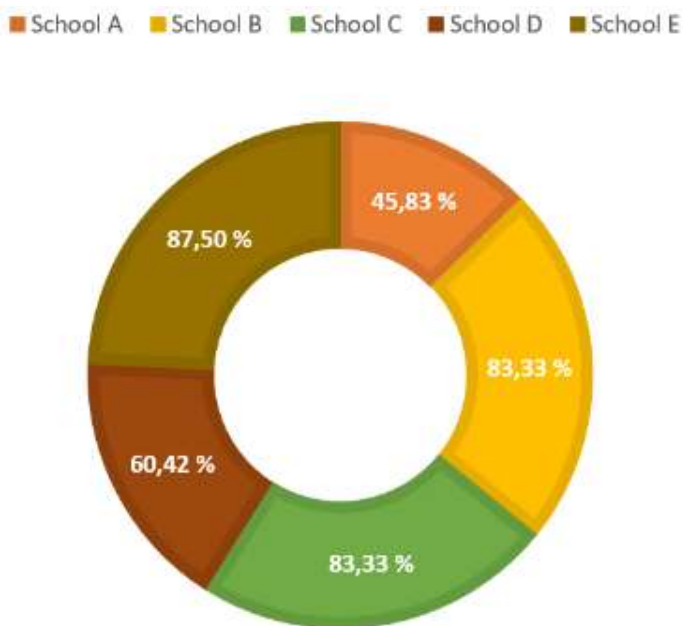

Figure 3. Percentage of students taking care of the school garden

Figure 3 shows that students $\mathrm{B}, \mathrm{C}, \mathrm{D}$, and $\mathrm{E}$ (Adiwiyata school) took care and cleaned the school garden more often with a percentage of $83.33 \%, \quad 83.33 \%, \quad 60.42 \%$, and $87.50 \%$ respectively. Student A only showed a percentage of $45.83 \%$.

The availability of easily accessible gardens at schools A, B, C, D, and E can encourage students to take care of the garden and interact with vegetation. The availability of a class's garden increases the percentage of students caring for the garden (the percentages of schools B, C, D, and E are higher than school A). The availability of indoor plants in schools B and E also increased the student interaction, evidenced by $83.33 \%$ for student B and $87.50 \%$ for student $\mathrm{E}$ which are higher than student $\mathrm{D}$ except for student $\mathrm{C}$ with a percentage of $3.33 \%$. The results of the significance test showed that the availability of green space affected student behavior in caring for plants by $13.5 \%$.

According to this result, the greenspace has no major effect on behavior, because the formation of behavior was more influenced by teaching and instruction to take care of the school garden. This is shown by the Adiwiyata school program (B, C, $\mathrm{D}$, and $\mathrm{E}$ ) which often conducted class hygiene competitions (including the class garden). Thus, to increase the behavior of caring for plants, schools should provide more green space and as close to students as possible, utilizing teaching and instruction on students.

ESchool A wSchool B mSchool C mSchool D aSchool E

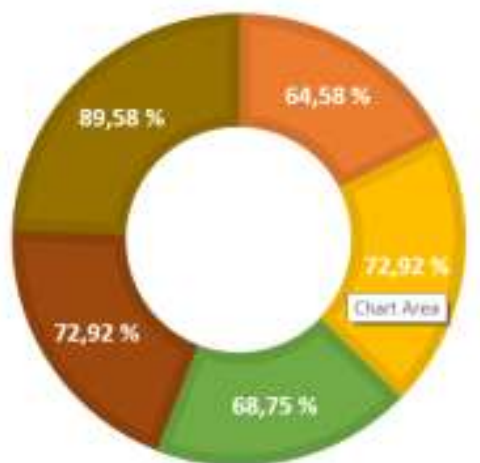

Figure 4. Percentage of students who do not turn on the lights

Figure 4 shows that students A, B, C, D, and $\mathrm{E}$ turned on the lights more often while studying in class with a percentage of $64.58 \%, 72.72 \%$, $68.75 \%, 72.92 \%$, and $89.58 \%$ respectively.

All schools have windows that extend in two sides of the classrooms with large openings and easy access to students. School E gets the highest percentage in carrying out this action because school $\mathrm{E}$ has the largest window area among the other schools. The results of the significance test showed that the width of the windows (openings) affected students' behavior to not turn on the lights by $13.3 \%$.

According to this result, the width of the windows (openings) has no major effect on behavior because the light in the classroom was possibly sufficient. Consequently, the interaction of students in the form of turning on the lights is relatively small. Thus, to improve the behavior of energy conservation, the school should continue providing a large opening for lighting and encourage the students to be aware of the conservation through the teaching.

\section{Conclusion}

The green-based schools play important role in supporting the development of student's environmental attitudes and behaviors, but it's also influenced by how long the school has implemented environmental-based education (Adiwiyata program). The results of the statistical 
analysis with IBM SPSS software showed that there was a positive relationship between the green-based school and student's environmental attitudes and behavior despite its weak correlation. The green-based school affects student's environmental attitudes by $9.3 \%$ and the environmental behavior of students by $12.3 \%$. A greater relationship was found in the student's environmental behavior (GEB scale) in school compared to students' environmental attitudes.

This study found that the higher greener features applied to schools, the more impact will be made in supporting the development of students 'environmental behavior. The presence of composter areas and waste banks in schools has increased student involvement in recycling. The more recycling space availability, the more significant recycling behavior was formed.

\section{References}

Almeida, C.M.V.B., F. Agostinho, B.F. Giannetti, and D. Huisingh. 2015. 'Integrating Cleaner Production into Sustainability Strategies: An Introduction to This Special Volume'. Journal of Cleaner Production 96 (June): 1-9. https://doi.org/10.1016/j.jclepro.2014.11.083.

Asyera, Erina. 2019. 'Correlation Between Green Building Environment and Sustainable Energy Behavior'. Universitas Indonesia.

BowoSantoso, Jarot Tri. 2015. 'Green School in the Perspective of Secondary School Students in Semarang, Central Java'. IOSR Journal of Research \& Method in Education 5 (6): 34$42 . \quad$ https://www.iosrjournals.org/iosrjrme/papers/Vol-5 Issue-6/Version3/G05633442.pdf.

Creswell, John W. 2012. Qualitative Inquiry and Research Design: Choosing Among Five Approaches. Edited by Third Edition. Sage Publications, Inc. California: SAGE Publications, Inc. https://doi.org/10.1111/1467-9299.00177.

Cummings, Neil. 2012. 'Fostering Sustainable Behavior Through Design: A Study of the Social, Psychological, and Physical Influences of the Built Environment'. University of Massachusetts Amherst, United States. https://scholarworks.umass.edu/cgi/viewcont ent.cgi?referer=https://www.google.com/\&htt psredir $=1 \&$ article $=2015 \&$ context $=$ theses.

Dewi, O C, I Chairunnisa, T Hidayat, M Anggraini, and A Napitupulu. 2018. 'Green Open Space: Awareness for Health or Sustainability?' IOP Conference Series: Earth and Environmental Science 120 (March): 012014. https://doi.org/10.1088/17551315/120/1/012014.

Djuwita, Ratna, and Aditya Benyamin. 2019. 'Teaching Pro-Environmental Behavior: A Challenge in Indonesian Schools'. Psychological Research on Urban Society 2 (1): 26. https://doi.org/10.7454/proust.v2i1.48.

Filippi, Marco, and Elisa Sirombo. 2015. 'Green Rating of Existing School Facilities'. Energy Procedia 78 (November): 3156-61. https://doi.org/10.1016/j.egypro.2015.11.773.

Goldman, Daphne, Ofira Ayalon, Dorit Baum, and Bell Weiss. 2018. 'Influence of "Green School Certification" on Students' Environmental Literacy and Adoption of Sustainable Practice by Schools'. Journal of Cleaner Production 183 (May): 1300-1313. https://doi.org/10.1016/j.jclepro.2018.02.176.

Griskevicius, Vladas, Stephanie M. Cantú, and Mark van Vugt. 2012. 'The Evolutionary Bases for Sustainable Behavior: Implications for Marketing, Policy, and Social Entrepreneurship'. Journal of Public Policy \& Marketing $31 \quad$ (1): 115-28. https://doi.org/10.1509/jppm.11.040.

Izadpanahi, Parisa. 2015. 'Green and Not Heard : The Relationship between Sustainably Designed Primary Schools and Children' $s$ Environmental Attitudes and Behaviours'. Deakin University Melbourne, Australia. https://dro.deakin.edu.au/eserv/DU:30082773 /izadpanahi-greenand-2015A.pdf.

Krysiak, N., F. Young, and C. Fearns. 2018. Environmental Design. New South Wales: Government Architect. https://www.governmentarchitect.nsw.gov.au /resources/ga/media/files/ga/manuals-andguides/better-placed-environmental-designin-schools-2018-10-29.pdf.

Kurisu, Kiyo. 2015. Pro-Environmental Behaviors. Tokyo: Springer.

Lockton, Dan, David Harrison, and Neville Stanton. 2008. 'Making the User More Efficient: Design for Sustainable Behaviour'. International Journal of Sustainable 
Engineering $1 \quad$ (1): $\quad 3-8$. https://doi.org/10.1080/19397030802131068.

Meiboudi, Hossein, Akramolmolok Lahijanian, Seyed Mohammad Shobeiri, Seyed Ali Jozi, and Reza Azizinezhad. 2018. 'Development of a New Rating System for Existing Green Schools in Iran'. Journal of Cleaner Production 188 (July): 136-43. https://doi.org/10.1016/j.jclepro.2018.03.283.

Ministry of Environment, Ministry of Education and Culture. 2012. Guidebook of Adiwiyata School Cares and Cultured the Environment. Jakarta Utara: Deputy Assistant for Strengthening Community Initiatives Deputy for Environmental Communication and Community Empowerment, Ministry of Environment.

NYC School Construction Authority \& NYC Department of Education. 2019. 'Green School Guide 2019'. NYC Green Schoo;s Guide. 2019. http://www.nycsca.org/Design/NYC-GreenSchools-Guide.

Pradono, Budi. 2019. 'The Interiority of Proximity Between Nature and Architecture in Contemporary and Tropically Context with Cases Studies'. ARTEKS: Jurnal Teknik Arsitektur 3 (2): $129-44$. https://doi.org/10.30822/arteks.v3i2.63.

Prochaska, James O., and Wayne F. Velicer. 1997. 'The Transtheoretical Model of Health Behavior Change'. American Journal of Health Promotion 12 (1): 38-48. https://doi.org/10.4278/0890-1171-12.1.38.

Ramli, Nur Hidayahtuljamilah, Mawar Haji Masri, Mohd Zafrullah, Haji Mohd Taib, and Norhazarina Abd Hamid. 2012. 'A Comparative Study of Green School Guidelines'. Procedia - Social and Behavioral Sciences 50: 462-71. https://doi.org/10.1016/j.sbspro.2012.08.050.

Razak, Nurul Hafiffah Bt. Abdul, Zanaton H. Iksan, and Sharifah Zarina Syed Zakaria. 2017. 'Students' Reflection on Green School'. Journal of Techno Social 9 (1): 44-52. https://publisher.uthm.edu.my/ojs/index.php/ JTS/article/view/1765/1148.

Stake, Robert E. 2005. The Art of Case Study. London: Sage Publication, Inc.

Subroto, Tarcicius Yoyok Wahyu. 2019. 'Koeksistensi Alam Dan Budaya Dalam Arsitektur'. ARTEKS: Jurnal Teknik Arsitektur 3 (2). https://doi.org/10.30822/arteks.v3i2.60.

Tucker, Richard, and Parisa Izadpanahi. 2017. 'Live Green, Think Green: Sustainable School Architecture and Children's Environmental Attitudes and Behaviors'. Journal of Environmental Psychology 51 (August): 20916. https://doi.org/10.1016/j.jenvp.2017.04.003.

Widodo, Johannes. 2019. 'Human, Nature, And Architecture'. ARTEKS: Jurnal Teknik Arsitektur 3 (2): 145-48. https://doi.org/10.30822/arteks.v3i2.65.

Yusup, Febrianawati, and Achmad Munandar. 2015. 'Developing a Valid and Reliable Environmental Attitude Instrument for High School Student'. Biologi, Sains, Lingkungan, Dan Pembelajarannya 12 (1): 292-96. https://jurnal.uns.ac.id/prosbi/article/view/67 $72 / 6100$.

Zhao, Dong-Xue, Bao-Jie He, and Fan-Qin Meng. 2015. 'The Green School Project: A Means of Speeding up Sustainable Development?' Geoforum 65 (October): 310-13. https://doi.org/10.1016/j.geoforum.2015.08.0 12.

\section{Author(s) contribution}

Restika R. Efiariza contributed to the research concepts preparation, methodologies, investigations, data analysis, visualization, articles drafting and revisions.

Ova Candra Dewi contribute to the research concepts preparation and literature reviews, data analysis, of article drafts preparation and validation.

Toga H. Panjaitan contribute to methodology, supervision, and validation.

Rizka Felly contribute to methodology, supervision, and validation. 